Miguel Luis Rocuant

\title{
La colina de las bienaventuranzas
}

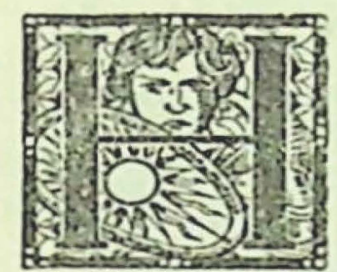

EMOS SUBIDO solos a lo más elevado de la colina. Queremos precisar la luz, las figuras y el paisaje que imaginamos al seguir la lectura de Mirián. Reconstruimos... La mañana es gris. Jesús baja, pensativo, de la altitud a que se retiró, en la noche, para orar. Suena, en el pedrerío, el paso de sus sandalias de cortezas. Próximo ya a quienes le aguardan, cede al orientalismo de sus costumbres y se sienta en el suelo, a la sombra de un árbol. Sabe que su doctrina de pasividad moral no podrá ser seguida, sin su ayuda, por el hombre. ¿Prometer ese auxilio? No. Eso despertaría, de seguro, el pensamiento utilitario de sacrificar lo efímero por lo eterno, y — ¿recuerda lo dicho en el testamento del patriarca José? - lo que regocija al Señor son los corazones puros. ¿Qué hacer? Consolar. Así podrá complacerse en la sinceridad de los que sigan su doctrina de resignación. Se pone de pie. Mira, une, tal vez, el desenvolvimiento de sus ideas a la clemencia de la claridad matutina. Luego, sin advertir que a esa hora rezan los que han bebido en la fuente de los profetas, en las divinas aguas de su verdad, murmura: Bienaventurados los pobres de espíritu... La lentitud de su voz parece adaptarse a la languidez perezosa de quienes le escuchan, mujeres reclinadas en el odre para el agua, viejos apoyados en el bastón. De pronto, luce, en el aire vaporoso, 
una pinta de ocre, después otra. El colorido de la mañana esclarece sus tonos asordinados, brumales. Se aproxima el sol. Jesús lo ve -es el calor que pone en el germen de la planta la certeza de la flor, y en el germen de las ideas la ambición del triunfo-, pero no le sonríc. Grave, casi triste, dice: Bienaventurados los mansos... Su promesa halaga el sedentarismo de sus oyentes. ¿A qué inquietarse por la vida si hay alguien que cuida de nosotros? Esperarán reunidos en sociedad estática. Parecen ignorar que la dicha no debe ser buscada por la mansedumbre ni por la agresión, sino por el trabajo. Cerca de aquí, han sido ofrendadas ya las primicias con que se anuncia el comienzo de la cosecha. El aire es dulce y cálido como la miel. Brilla, en la perspectiva agraria, el trigo. Se oye mugir al buey que trillará, libre de bozal, para que pueda pagarse su faena, como lo dispuso la piedad mosaica. Algunos segadores fatigados beben vinagre con agua, y sueñan con el descanso. Pronto - terminada la siega - volverán al hogar, siguiendo la carreta en que las últimas gavillas irán adornadas, según la costumbre, de lirios y rosas. Son los días del trabajo alegre, porque redime del hambre y promete el amor. Jesús lo sabe $\mathrm{y}$, sin embargo, sus palabras no inducen, bajo el cielo de añil, frente a los confines de fuego, sino a la resignación dolorida: Bienaventurados los que lloran...

(Del libro inédito Paisajes del Evangelio). 